\title{
Leisure, luxury and urban specialisation in the eighteenth century
}

From hence we came ... to Shrewsbury. This is indeed a beautiful, large, pleasant, populous and rich town; full of gentry and yet full of trade too; for here too, is a great manufacture ... which enriches the country round it. ${ }^{1}$

One of the most remarkable distinctions drawn between urban development of the pre-modern and modern periods is the emergence of specialist towns. For the period up to about 1700, historians have differentiated towns principally in terms of size: the 'great and good towns' being distinguished from county and small market towns. After that date, a growing range of urban types is recognised, including resort towns, manufacturing towns, transport centres and dormitory towns. ${ }^{2}$ In this process, the eighteenth century can be seen as a crucial phase of development, when many of these 'new' types of town emerged or proliferated. Thus Corfield's labelling of this as 'one of the most mutable periods in English urban history, ${ }^{3}$ applies not just to the relative size of different towns, but also to their function and character. This burgeoning specialisation was dependent upon the growing integration of economy and society, regional and national space, and urban systems." As Robson, Pred and Lepetit have argued, the economic and social functions of towns were carried out in an interconnected framework that both determined the collective and individual role that towns can play in wider development and stimulated growth and the nature of growth within those towns. ${ }^{5}$ Improved transport and communication services afforded better linkages between places, allowing people, goods and information to circulate more rapidly and bringing towns into much closer contact. This meant that urban functions were organised less as hierarchical systems, with centres being distinguished in terms of the range and number of activities found therein and more as networks of specialist centres, closely interdependent upon one another for supplies and markets. ${ }^{6}$ Thus, for example, resort and leisure functions were increasingly concentrated onto a specific set of towns - the inland spas and later coastal resorts, more generally grouped under the heading 'leisure towns' ${ }^{7}$

To what extent, though, is this notion of specialisation really valid for the eighteenth (or even the nineteenth) century? Reeder and Rodger note the growing economic diversification found in many industrial towns in Victorian Britain as the service sector became increasingly important, especially in larger towns. Borsay has long held that environmental improvement, economic revival and the spread of 'polite' culture in the century after the restoration was widespread and symptomatic of a general urban renaissance. And Trinder has demonstrated the spread of manufacturing into many small market towns during the industrial revolution. ${ }^{8}$ Does this make the identification of specialist towns little more than part of a modernist agenda to classify and categorise? Can we really identify manufacturing towns or leisure towns in terms of their economic structure, their infrastructure or their function within wider urban systems? As a glance through Defoe's Tour reveals, 
contemporaries tended to frame their descriptions around notions of 'good company'. ${ }^{9}$ There is certainly plenty of evidence to suggest that neither leisure nor manufacturing was restricted to their supposedly specialist locations.

One of the most striking indications of this eighteenth-century hybridity comes with Schwarz's identification of so-called 'residential leisure towns'. Based on analysis of the 1780 returns of a government tax on manservants, he defines these towns as places with thirty or more employers of manservants. ${ }^{10}$ What is notable about this list is that it includes a huge variety of different 'types' of town. There are many places which we might expect to see: Bath, York, Chester, Shrewsbury and Bury St Edmunds would feature on many people's list of 'leisure towns'. These were generally, if sometimes grudgingly, acknowledged by eighteenth-century writers as places of note, where good company generated a cultured and polite urban society. ${ }^{11}$ But Schwarz's listing also includes a large number of commercial and manufacturing towns which do not fit conventional notions of a leisure town: for example Manchester, Liverpool, Plymouth, Birmingham, Hull, and Yarmouth. Moreover, there are several very small towns - Monmouth, Stafford and Peterborough, each with a population of under 4,000 in 1780 - for which the label 'leisure town' might seem equally ambitious. Could such diminutive places really sustain the kind of urbane life expected by the leisured classes?

Yet these reservations perhaps reveal more about what we expect to find and what we think we know about such places, than they do about the reality of their infrastructure, socio-economies and culture. It is clear that the list of residential leisure towns does tell us something about which places were the late eighteenth-century centres of leisure and luxury. How exactly we might define luxury is problematic and certainly more complex than simply equating it with non-essential consumption. Berg suggests that definitions 'were always historical' and argues for a fundamental shift in meaning between the early modern period and the eighteenth century, when luxury was freed from the strictures of sumptuary laws and became increasingly associated with notions of taste and fashion. ${ }^{12}$ Despite this, its association with status and identity remained strong: the residential leisure towns did have some things in common. Employing a manservant was, in many ways, the ultimate luxury. It fits precisely Veblen's notion of conspicuous consumption: that is, an unnecessary expense designed to enhance the comfort and status of the employer. Not only was there little that a manservant could do that a woman could not do and do more cheaply', the tax was not payable if manservants could be defined as having regular employment elsewhere. ${ }^{13}$ Such practices probably reflect an emulation of aristocratic and metropolitan behaviour, but were sufficiently widespread to suggest that they were important in defining at least one form of gentility. The presence of significant numbers of such flunkeys and their employers suggests four things about the places in which they were found. First and foremost, there was a concentration of wealthy people with money to spend. Second, these people wanted to display their wealth in a very public way. Third, there were other groups and individuals to whom this display was directed and had mutually understood meanings. And fourth, there were venues and opportunities to carry out such conspicuous 
consumption. Extending this reasoning further, it follows that these wealthy individuals would have been looking to demonstrate their wealth in other ways as well: by consuming luxury goods and services, and by patronising and encouraging what was at least locally considered to be 'polite' culture. In other words, we would expect towns with large numbers of wealthy employers of manservants to offer elite leisure activities and provide good access to luxury goods through a welldeveloped retail sector, not least because such provision would help to attract families of rank to settle in the town in the first place. ${ }^{14}$

By indicating the prevalence of such motivations, opportunities and activities, the identification of residential leisure towns challenges our perception of the (growing) divide between leisure towns and commercial towns in the late-eighteenth century. It also brings into question the more general divisions made by historians between types of towns. But how real was this grouping? Besides the residence of wealthy individuals, what drew together residential leisure towns and distinguished them from other towns? Does the designation really mean anything in terms of the nature of these towns and their provision for wealthy consumers? The purpose of this paper is to address these broad questions by examining leisure and luxury provision in both residential leisure towns and a 'control' group of thirty-five other towns. ${ }^{15}$ The latter include county towns, other towns (mostly commercial or manufacturing centres) with populations over 10,000 in 1801, and smaller or emergent 'resort' towns - all places that might have pretensions to be (residential) leisure towns. Specifically, we seek to establish whether residential leisure towns provided a range of infrastructure, facilities, goods and services for a leisured lifestyle, and whether their provision was quantitatively or qualitatively different from that seen in the control group. To do this, we draw on the original data on manservants (extending the analysis beyond the fifty-three towns identified by Schwarz), and supplement this with information on service and leisure provision drawn in each town. ${ }^{16}$ This statistical analysis is given greater depth by more detailed material on selected towns drawn from probate inventories, town histories and so on. The aim is not so much to judge the usefulness of the label 'residential leisure town', but rather to explore the spread of leisure and luxury through the urban network. At a more general level, this feeds into debates over the geographical and hierarchical spread of an eighteenth-century urban renaissance as well as those concerning the whole notion of urban specialisation and how it might be defined and measured.

\section{Leisure and improvement}

Residential leisure towns are defined in terms of a particular form of conspicuous consumption, but many of the towns identified in this way had long been established as important places marked by fine buildings and the assemblage of 'good company'. Each of the top ten residential leisure towns had been described by Blome as 'well inhabited', 'well frequented' or 'much resorted to' (see Table 1) - an indication of their attraction as key centres of commercial and social interaction. Moreover, 
there is a striking contrast in descriptions of those places which did or did not make the grade in 1780. Hertford, for instance had been dismissed with the comment that it 'hath been of greater state, estimation, and beauty, than now it is'; and indeed in 1780 it failed to pass the threshold for a residential leisure town. In contrast, Northampton, which had been praised by Blome as 'a town of considerable trade' and by Defoe as 'the handsomest and best-built town in all this part of England', did pass the threshold. ${ }^{17}$ There is also a close relationship between the towns with large numbers of employers of manservants in 1780 and those where many households were paying silver plate duty a generation earlier, in $1757 . .^{18}$ Whilst both of these taxes were on 'luxuries', the showy nature of manservants contrasts somewhat with the more sober and inherited wealth suggested by the ownership of silver plate, at least in the 1750 s - probably the last decade before the explosion of silverware throughout much of the middling classes. ${ }^{19}$ Nonetheless, the correlation between the rank order of the two measures is significant at 99.9 per cent, suggesting that, from the middle of the eighteenth century at least, there was strong continuity in those places favoured by wealthy elites. Stability was most notable at the top of the respective hierarchies. Of the ten towns with most households liable to the silver plate duty, eight were in the top ten residential leisure towns (see Table 1). That said, the position was not entirely stable, with manufacturing towns often rising up the hierarchy: Birmingham went from seventeenth in mid century to tenth by 1780 , and Leeds from nineteenth to eleventh.

\section{TABLE 1}

What is it, then, that made certain places attractive as residential leisure towns? As noted in their original designation, residential leisure towns - and by implication the spatial foci of leisure and luxury - were predominantly county towns, especially if this definition is broadened to include de facto county towns such as Preston as well as official county capitals. ${ }^{20}$ Moreover, a number of the large commercial centres, which made up the second largest group of residential leisure towns, also contained important county functions by the late eighteenth century - Bristol, Newcastle and Leeds, for example, all had quarter sessions. Conversely, relatively few county towns were not included in Schwarz's original designation and, of the 'control group' studied here, several others were close to meeting the threshold criteria of thirty employers of manservants: Huntingdon and Hertford each had twenty-seven, whilst Bedford had twenty-four. All this is, perhaps, unsurprising. The administrative functions of county towns inevitably formed an attraction to the rural gentry and a powerful and wealthy urban elite as assizes, quarter sessions, elections, shire halls and the like cemented links with the county and with London. As Elliott puts it, their juridico-political and ecclesiastical status allowed them to ... "punch above their weight" in cultural terms'. ${ }^{21}$ In contrast, commercial towns were characterised by a much higher proportion of labouring sorts who would have been unable to engage in such leisure and consumption. Compounding this, many smaller 
manufacturing towns often lacked or were slow to develop an indigenous middling sort. Yet these social and political distinctions are not enough to explain the location and nature of residential leisure towns: half were not the centres of county administrations and besides, as Ellis argues, there had to be other attractions to keep these wealthy individuals resident in these places. ${ }^{22}$

To function effectively as centres of leisure and luxury, towns needed to be refined and orderly, with evidence of improved streets, buildings in the latest architectural style and a range of civilised and civilising institutions and activities. ${ }^{23}$. As David Hume commented, people love to receive and communicate knowledge; to show their wit or their breeding; their taste in conversation or living, in clothes or furniture'. ${ }^{44}$ This links leisure and consumption to sociability, to urban and commercial society, and to the reconstitution of urban economy and culture. Critics of Borsay's theory of urban renaissance have questioned both the extent to which improvements and new cultural infrastructure were manifest beyond a relatively restricted number of leisure towns and the timing of any spread down the urban hierarchy. ${ }^{25}$ This would imply that leisure and luxury were largely the preserve of few rather than many places, and that anyone wishing to tap into such culture and lifestyles would need to reside in or visit these towns. The evidence here lends some support to these critiques and underlines the status of residential leisure towns as the principal centres of leisure and luxury. However, it also demonstrates that many lesser towns were part of the wider eighteenth-century cultural and economic renaissance of towns.

In order to attempt systematic analysis of the distribution of 'polite' culture and urban improvement, a sample was taken of eight leisure facilities and aspects of improvement: assembly rooms, theatres, libraries, horse racing, walks/gardens, music concerts/societies, improvement acts and town histories. Rather than trying to establish the precise date of establishment of every facility and activity, we have simply recorded the presence or absence of each in the sample towns. Even this is a complex and potentially endless process: whilst the presence of a function is usually clear enough;26 its absence could be real or might simply reflect the fact that it has not been recorded, or that any recording has not been found. The figures that follow are therefore best seen as minima - we can be certain that the various towns contained at least the functions noted. Yet, despite these reservations, the established patterns seem clear and revealing of the concentration of leisure and luxury in the eighteenth-century urban network.

TABLE 2

Of the eighty-eight towns surveyed for this study, around one-quarter are known to have possessed at least seven of the eight sampled leisure facilities and improvements by 1790, and more than twothirds had at least four (Table 2). Most widespread were assemblies, races and town halls, whereas music concerts, libraries, and especially formal residential squares were restricted to the larger 
centres. Overall, such developments were much more common amongst the residential leisure towns: nearly one-quarter possessed all the selected facilities, whereas just one of the 'control' towns appears to have been so well served.27 This contrast holds good for both county and commercial towns. Thus, for example, Lancaster and Lincoln had a wider range of elite leisure facilities than did Warwick and Carlisle; whilst Manchester and Yarmouth were better provided than Sheffield, Sunderland or Wolverhampton. Those towns without a large number of wealthy residents generally enjoyed assemblies and theatres, but often lacked promenades, libraries or music concerts, certainly before the turn of the nineteenth century. Race courses too appear to have been concentrated into the residential leisure towns, 85 percent of which hosted horse racing compared with just 37 percent of the control group. This undoubtedly reflected the 1740 Act which, in stipulating a minimum prize of $£ 50$, had caused the closure of many smaller race meetings; yet the nature of those places that remained centres of horse-racing is surely significant: a local wealthy elite providing important patronage of such events. ${ }^{28}$ Indeed, there is a more general and undoubtedly causal relationship between the number of wealthy residents (as indicated by employment of manservants) and this growing infrastructure of elite culture. The best-provided towns had, on average, 118 employers of manservants; those with three or four of the sampled leisure facilities had fewer than forty employers. Neither the rank order correlation nor the $t$ statistic between the residential leisure towns and the control group are significant at the $5 \%$ level. ${ }^{29}$

Notwithstanding the importance of visitors from the surrounding countryside and further afield, many promoters, subscribers and users would have been drawn from this set of wealthy residents. This is apparent from Beckett and Smith's analysis of urban renaissance and consumption in Nottingham from which they conclude that the same individuals were central to both processes in the town. ${ }^{30}$ Thus, resident gentry not only helped to define politeness by their presence in a town, they also played a significant part in developing other aspects of this polite status. The pivotal role of Lord Brooke in shaping the post-fire reconstruction of Warwick is well known; yet urban gentry were also instrumental in the nascence of Burslem's urban infrastructure: those sponsoring the construction of the first 'town hall' in 1761 included the two Lords of the Manor (Sir Nigel Gresley and Ralph Sneyd, esquire), as well as a long list of local pottery manufacturers. ${ }^{31}$ Given this, it is especially significant that the well-provided places included manufacturing centres, underlining the fact that such places contained substantial numbers of wealthy residents and consumers - often many more than established county towns nearby - and increasingly took over from them as regional centres. This changing balance of power can best be seen in the case of Birmingham and its relationship with neighbouring towns. Blome allowed Birmingham ('a large and well-built town') a mere seven lines, compared with 32 for Coventry ('a fair, neat and large city') and 29 for Warwick ('a place well inhabited') and 33 lines for Lichfield (' well-built, indifferent large ... and much frequented by the gentry'). ${ }^{32}$ A century later, the industrial giant easily overshadowed its neighbours. It had 104 employers of manservants and enjoyed the full range of leisure facilities and improvements, including theatres and assembly rooms, two sets of pleasure gardens, a Musical and Amicable Society (1760s), 
Subscription library (1779), and Literary and Philosophical Society (1799). In comparison, Coventry, with forty-six, Warwick with twenty-three, and Lichfield with just twelve employers, had all experienced more limited leisure development. ${ }^{33}$

The cultural and environmental improvement of commercial and manufacturing towns was largely restricted to major centres before the last quarter of the eighteenth century when we see, for example, a group of Lancashire textile towns, hitherto under-endowed with facilities for polite leisure, gaining theatres, libraries and improvement acts. Blackburn, for example, had a Handel Society by 1754 , a library some time before 1770 , a theatre by the 1780 s, and an improvement commission from 1802. ${ }^{34}$ Much the same appears to have been the case for many lesser county towns. Although facilities for elite leisure were found by mid century in surprisingly small places - witness Fakenham's subscription concerts and Spalding's Gentleman's Society (the latter a reflection of the town's large number of lawyers, but remarkable nonetheless) ${ }^{35}$ - towns like Dorchester and Hertford were probably more typical. Leisure development remained limited in both, partly because of the attractions of neighbouring centres such as Weymouth and St Albans, but also because of the lack of a critical mass of wealthy consumers.

This distinction between residential leisure towns and other places - between centres of leisure and luxury, and those more marginal to, though still very much part of, the cultural and consumer changes that marked the eighteenth century - was epitomised by the production of town histories. Whilst they were written for a wide variety of purposes, such histories were important markers of urban status and said much about the cultural pretensions of a town. ${ }^{36}$ All but six of the fifty-three residential leisure towns had town histories by 1820, thirty-two being written before 1790. In contrast, just seven of the other towns surveyed had histories written before 1790 and only another eleven produced histories over the subsequent thirty years. The omissions are instructive. Of the residential leisure towns, it was generally smaller county towns or social centres (places such as Stafford and Peterborough) that failed to produce town histories. In the other group, county towns including quite small places like Buckingham and Warwick - often had histories, whereas even fairly large manufacturing centres (Wolverhampton, Dudley and Stockport) were without them. In part this reflected the presence of a corporation and a set of municipal records which respectively formed important markets and sources for such studies. However, a large body of wealthy residents was also significant: in direct terms they were potential subscribers; more generally, they appear to have been important in nurturing a strong sense of civic identity - an awareness of self and other - which underpinned the production and market of town histories.

Of course, contemporaries judged the status of a town as an attractive and important centre of luxury and leisure more by the quality of its facilities than by their sheer volume. For instance, whilst substantial houses and terraces were built for the burgeoning middling sorts in many places, ${ }^{37}$ lesser towns generally lacked the formal squares and crescents that characterised some of the major centres like Bristol, Liverpool, Birmingham and Chester, at least until the closing years of the 
eighteenth century. And few places could match the grandeur of the redevelopment of Bath, masterminded by the Woods. ${ }^{38}$ Similarly, the grandest facilities for polite leisure, and the most glittering array of subscribers and visitors, were to be found in the major residential leisure towns. Once more Bath stood out, but the assembly rooms at York, Liverpool and Lincoln amongst others were lavishly and expensively decorated. The ballroom in the Guildhall in Worcester, for instance, was wainscoted up to a height of seven feet, with plaster work above, and was illuminated by three large sconces hanging from the ceiling, plus twenty-two smaller ones attached to the walls. ${ }^{39}$ Equally, whilst the King Street theatre in Bristol (built 1764-6 at a cost of £4800) was the largest outside London, theatres in lesser towns were often poor places and could be very short-lived, that in Nantwich, Cheshire being described as 'a plain piece of architecture [in] an obscure and ineligible situation'. ${ }^{40}$ That said, quality and profitability were not assured even in more substantial residential leisure towns: the manager of Gloucester's Barton Street theatre complained of it being a 'melancholy, inconvenient place, which, when filled, would not hold more than thirty-five pounds', whilst Defoe said of Bath's theatre that 'the decorations are mean and the performances accordingly'. ${ }^{41}$ Despite such reservations, it is apparent that residential leisure towns provided not simply a greater range, but also better quality infrastructure: a more conducive environment for leisured and would-be polite society.

\section{Luxury: access to goods and services}

If provision of good quality cultural facilities within an improved urban environment was one important part of what distinguished residential leisure towns, then another was the availability of a range of luxury goods and services. People were increasingly judged according to their appearance and manners; their homes and lifestyles. ${ }^{42}$ As Defoe noted: 'anything that looks like a gentleman, has an address agreeable, and behaves with decency and good manners, may single out whom he pleases'. ${ }^{43}$ As a result, knowledge of current tastes and fashions; access to the right clothes and furniture, and the acquisition of appropriate social skills (for example: dancing, drawing, music and languages - especially French and Italian) became central to defining both individual identity and membership of 'polite' society. ${ }^{44}$ Towns that were to be centres of this kind of sociable yet genteel and leisured society needed to be able to supply these needs. In this second stage of analysis, we therefore explore the number of luxury retailers and service providers in a variety of selected areas. These can be broadly grouped under three headings: luxury retailers/craftsmen (coachmakers, clockmakers, glass or china dealers, gold- or silversmiths, jewellers, mercers, perfumers, toymen and upholsterers), professionals (architects, attorneys, dentists, opticians, physicians, and surgeons), and the arts (booksellers, dancing masters, drawing masters, music sellers and portrait painters).

For this, data were taken from the Universal British Directory $(U B D)$ This is by no means a perfect record and, whilst coverage of luxury trades is generally quite good, it is clear that certain places are poorly covered: the entry for Leeds, for example, lists just eleven trades and forty-five tradesmen in 
the 'luxury' sector, figures which compare badly with those of Ryley's directory. However, there is little evidence that the compilers served particular types of towns better or worse than others. ${ }^{45}$ If Leeds was poorly covered, other large commercial centres had very full listings: that for Manchester, for example, includes twenty luxury trades and over 250 tradesmen (comparable with numbers in Raffald's directory). Some smaller towns were well covered; others more sparsely: Blackburn had eight trades and forty tradesmen, whilst Walsall had just four and eighteen respectively. Equally, county towns could have what seem to be full listings (Chester's seventeen trades and 117 tradesmen looks about right when compared with the 1780s directories of Broster and Cowdroy), but others were apparently less complete (Preston had only ten trades and fifty tradesmen). ${ }^{46}$ Of course, it would be desirable to check the $U B D$ against what are probably more reliable local directories or even against newspaper advertisements, but this is only possible in those places where such sources exist - and they are absent for many smaller towns. Moreover, the impression from the figures outlined above is that the picture is mixed, but generally favourable: certainly, there are few towns in our sample where the numbers look suspiciously low. Ultimately, then, the only realistic option is follow other analyses which have drawn on this source and take the totals given in the UBD, acknowledge their short-comings, but recognise that they probably do not seriously affect the overall patterns revealed.

From the $U B D$, then, we took the number of luxury trades (as defined above) and the total number of luxury tradesmen, the two numbers being multiplied together to give a 'luxury service score' for each town. ${ }^{47}$ Whilst in some ways crude, this technique at least allows us to account for both the breadth and depth of provision, and to test the concentration - or otherwise - of luxury retail and service provision into particular towns. Despite the caveats made above, these data clearly show that residential leisure towns dominated the upper reaches of the service hierarchy. All but one of the eighteen towns that had fifteen or more of the selected luxury trades were residential leisure towns, the only exception being Nottingham - a seeming anomaly in the records of manservants, probably omitted from the original Treasury list of employers of manservants. More telling still are the luxury service scores (see Table 3). Here, Nottingham is the only non-residential leisure town in the top twenty; and only seven feature in the top forty. Looked at differently, well over one-third of the residential leisure towns had scores of 750 or more, compared with just 3 per cent of the control group. These figures are significant as they underline the reality of this as a grouping of towns: residential leisure towns not only housed large numbers of affluent individuals anxious to show off their wealth by employing manservants; they also formed major concentrations of traders able to supply these people with a wide range of luxury consumer goods and services. Statistically, the correlation between numbers employing manservants and luxury service scores is significant at the 99.9 level; 48 for contemporaries, it meant that residential leisure towns gave ready access to a burgeoning world of goods: the trappings of a leisured lifestyle. 


\section{TABLE 3}

Also important is the fact that these concentrations are more effectively explained in terms of residential leisure than other typological differences - a distinction which further strengthens our conviction that the $U B D$ does not contain a systematic bias. Towns with better provision of luxury goods and services did not tend to be of any one particular type. County towns were the most numerous amongst those centres with scores above 750 , accounting for twelve out of twenty-one of these higher order centres (see Table 3). But a similar proportion of the selected county and commercial towns (around one-third in each case) were above this threshold, whilst resort towns were notably under-represented in the upper reaches of the service hierarchy - Bath forming the only exception. ${ }^{49}$ Indeed, it was the large commercial centres that were especially prominent at the very top of the service hierarchy. Clearly, providing for a set of wealthy consumers was not the preserve of either resorts or county towns. Rather, it spread to incorporate established and more recently emergent commercial towns, including Bristol and Newcastle; Liverpool, Birmingham and Manchester - a reflection of this group's growing status as regional capitals. ${ }^{50}$. In short, what seems to have mattered most in determining the level of service provision was the presence of a set of wealthy consumers who were willing to spend on an expanding range of luxury and semi-luxury goods, not the economic character of the town or the reasons why those consumers lived there.

Of course, one reason why these major centres dominated the service hierarchy - even for luxuries was that they were very large. Inevitably, they had more potential consumers than their smaller neighbours and were more likely to have large numbers of tradesmen appearing in the UBD.51 Recalculating the scores to allow for different levels of population paints a rather different picture of the provision of luxury goods and services. Residential leisure towns still dominate the service hierarchy, accounting for seventeen of the top twenty and fourteen of the top forty towns, but commercial towns are far less prominent than before Whereas in absolute terms, they accounted for five of the top ten; when their service score is expressed as a ratio of population, only three feature in the top twenty. ${ }^{52}$ Their places at the top of the hierarchy are taken by county towns: Worcester, York, Chester and Exeter stand out. Here, exceptional provision of luxury trades per head of population was undoubtedly related to their well-established position within county social, cultural and service structures. The extensive hinterlands and links with the surrounding countryside which these places enjoyed - precisely the qualities which made them attractive as leisure towns - served to bolster their service sectors. They were providing not simply for their own populations but also for demand from smaller towns and rural residents. ${ }^{53}$

These arguments may seem convincing, but we need to be cautious about how far we take them. Manufacturing towns may not have operated as traditional central places, but many developed extensive links with often very large hinterlands. From her home near Colne, Elizabeth Shackleton purchased goods from a variety of towns, including Lancaster (the county town), but also 
Manchester. Half a century later, Anne Lister bought from retailers as well as using cultural facilities in her local town of Halifax, seemingly without being concerned about its 'industrial' character. She also made shopping trips to York - often combining these with visits to friends - and took the opportunity of journeys to Manchester to purchase particular goods, notably jewellery. ${ }^{54}$ It is unlikely that such consumers knew or cared much about the ratio of shops to population: they were more concerned with the availability and quality of the goods and services they sought. Significantly, insofar as the $U B D$ listings can be relied upon, commercial and manufacturing towns were often just as likely as their county town neighbours to contain the rarest luxury trades (Table 4). Indeed, these luxury trades could turn up in the most surprising of places, and included an architect in Doncaster, an optician in Sheffield, and portrait painters in Macclesfield and Wolverhampton.

\section{TABLE 4}

Quality, of course, was a different matter, and is much harder to judge, especially from simple listings in directories. It is possible that the county towns contained a better class of tradesman, but the evidence for this is inconclusive. Probate inventories indicate that specialist shopkeepers in quite small towns offered an enormous range of goods. For example, from his shop in Congleton Zachariah Shelley sold a range of groceries and haberdashery as well as tammies, shalloons, tansies, serges, worsteds, flannels, fustians, checks, canvas, callicoes, crepes, silks, lace and mohair. In Stockport, Richard Upton, specialised more in woollen cloths, but also carried mohair, silk, and gold and silver threads; whilst James Rathbone of Macclesfield sold printed calicoes, muslins, ribbon, silks, velvets and lace; plus oils, Hungary waters, hair powder, books, cravats, handkerchiefs, fans, stockings, cloth and leather gloves and even a sable muff. ${ }^{55}$ Yet the overall shopping experience in places such as Macclesfield and Stockport undoubtedly fell far short of that in Chester, where shops were more numerous, often high status, and drew customers from across the county and north Wales. ${ }^{56}$ The shopping streets in Bath, Chester and Worcester were portrayed as being more fashionable than those in Wolverhampton and Sheffield, or even Manchester and Birmingham. Comparisons were drawn with London's Cheapside or, slightly later, Regent Street; the effect being to link local retailers with the metropolis as centre of fashion and supply. ${ }^{57}$ Moreover, the major centres, and especially the key resort towns, attracted more famous and talented entrepreneurs, artists and performers. Whilst Sarah Siddons seems to have performed in most of the principal theatres in the country (an association which the writers of town guides were always enthusiastic in proclaiming), Garrick and Kean restricted their activities to a few major centres. Visiting composers also limited their orbits: Haydn, for example, spent most of his time in London, only making a few trips outside the capital to notable centres such as Oxford and Bath. Indeed, few other towns could match the quality of Bath's artistic and cultural life, as its citizens and visitors could call on the services of men such as Gainsborough, Lawrence, Hoare, Rauzzini and Herschel. ${ }^{58}$ 


\section{Conclusions: leisure, luxury and perceptions of politeness}

The quality of goods and services - as with the quality of residents - reflected on the status of the town. But here, perceptions were often more important than reality, and the line of reasoning increasingly ran in the opposite direction. The socio-economic character of a town coloured judgements about its 'politeness' and thus perceptions of the quality of goods, services and facilities found therein. Sweet argues persuasively that, just as the tradesmen and nouveau riche merchants become stereotypical figures of vulgarity', so the towns they inhabited were labelled as impolite. Indeed, they became a 'rhetorical anti-type' allowing notions of politeness to be defined ever more closely around the attributes of the gentleman and the places they inhabited. ${ }^{59}$ The kind of rhetoric that portrayed Liverpool as a cultural desert without 'a single erection or endowment, for the advancement of science, the cultivation of the arts, or the promotion of useful knowledge' was reinforced by the loss of key elements of its leisure infrastructure and the problems in establishing new cultural institutions in the town. ${ }^{60}$ As with many other commercial towns, Liverpool was portrayed as a place of commerce, not culture; as lacking in pedigree and taste. And yet the evidence of employers of manservants, the provision of leisure and the availability of luxury goods and services reveals these places to be centres of leisure and luxury - that is, residential leisure towns. New trends in leisure and fashions in consumption may have been set in London and the resorts, but most people obtained their luxuries and took their leisure closer to home, even when increasing accessibility took the shine off the social seasons of many county towns. ${ }^{61}$ After the visit of George III, for example, England's fashions were 'Cheltenhamised', but the newly fashionable fabrics and dresses were available from mercers and milliners across the country. Moreover, shopkeepers were anxious to advertise their awareness of and access to London fashions. The Liverpool mercer, P. Prichard, was typical, announcing that:

he has just come down from London as great a variety of the different new patterns calculated for the spring, as the earliness of the season would admit of, and will make a point of furnishing himself, by all the weekly conveyances, with such others, and those of the most elegant fancy, that are now making for the approaching months. ${ }^{62}$

Prichard's point was three-fold: firstly, fashions were changing rapidly; secondly, London was the supply centre for these fashions, and thirdly, he was well-placed to supply consumers with both knowledge of the latest trends and the goods themselves.

This widening access to fashion, manners and taste - affected through newspapers and pattern books, provincial shops, the burgeoning literature on etiquette, and the efforts of dancing masters, language teachers and the like - effectively spread the boundaries of politeness both for people and places. In a way, this was part of the problem. By the later decades of the eighteenth century, 
politeness was becoming less exclusive and therefore needed to be redefined as something out of the reach of most people (by their birth) and most places (by their history and socio-economic development). ${ }^{63}$ There is thus a growing dissonance between the reports of metropolitan-inspired travel writers and the array of goods and services, institutions and improvements found in many residential leisure towns. The most dynamic places and best-served places were increasingly the great commercial centres rather than the established county towns. By the time that Manchester was being described by Torrington as a 'dog hole', there was already an Agricultural Society (1767), a Literary and Philosophical Society (1781), and College of Arts and Sciences (1785) in the town, whilst its inhabitants could enjoy the services of two music masters, two dancing masters, a musical instrument maker and a miniature painter. Such an array of functions was some distance in advance of, but also different in character from that found in Chester, the traditional regional capital, which remained focused on more overtly leisure rather than 'improving' activities. ${ }^{64}$ And yet Chester was more widely acknowledged as a place of resort, both for visiting and resident gentry. The key was, perhaps, less in what was to be found there, than what was not. As one contemporary commentator argued, it was 'the absence of manufactories, and the crowds of the lowest rabble they engender' that made it 'a desirable residence for the higher classes' ${ }^{65}$

These contrasts in facilities and image encapsulate the complex and unstable ways in which status was accorded to towns in eighteenth-century England. In systematic surveys of the urban network, it is too easy to equate demographic size with importance, ignoring other, more subtle and yet more meaningful measures of urban status. Population was important - witness the furore that followed the publication of the first census ${ }^{66}$ - but the socio-economic and cultural characteristics of that population were perhaps more telling, particularly when linked with the presence of certain cultural and civic infrastructure. Sweet discusses these attributes in terms of politeness - a term which conveyed much to contemporaries, but which defies easy definition: it is far easier to say which places were polite, and which were not, than to explain why they might be viewed in this way. Our analysis suggests that the designation 'residential leisure town' might be used as another means of defining the status of towns as more or less attractive centres of conspicuous consumption and elite sociability. Contemporaries did not, of course, talk about residential leisure towns, but they appear to have thought in similar terms, describing the presence of 'good company' in certain places, and according status to those places which were able to attract a (resident) gentry population. This attraction was based, in part on the presence of other wealthy residents (and the relative absence or perhaps more correctly the lower visibility of the poor), but also on the leisure infrastructure and luxury service and retail facilities present in these places. It was this combination of social profile, built environment and cultural-economy that made these places distinctive: not their demographic, political or socio-economic make-up. Accepted notions that urban typologies are most appropriately organised around growing functional specialisation might usefully be tempered, therefore, with older-established and more subjective categorisations based on the status of the town. 


\section{Appendix I.}

\section{Residential leisure towns ${ }^{67}$}

Bath, Berwick, Beverley, Birmingham, Boston, Bristol, Bury St Edmunds, Cambridge, Canterbury, Chester, Chichester, Colchester, Coventry, Derby, Doncaster, Dover, Durham, Exeter, Gloucester, Hereford, Hull, Ipswich, Lancaster, Leeds, Leicester, Lewes, Lincoln, Liverpool, Lynn, Manchester, Monmouth, Newark, Newcastle, Northampton, Norwich, Oxford, Peterborough, Plymouth, Portsmouth, Preston, Reading, Rochester, Salisbury, Shrewsbury, Southampton, Stafford, Stamford, Wakefield, Winchester, Windsor, Worcester, Yarmouth, York

\section{Control group}

Bedford, Blackburn, Bolton, Bradford, Brighton, Buckingham, Buxton, Carlisle, Cheltenham, Dorchester, Dudley, Halifax, Harrogate, Hertford, Huddersfield, Huntingdon, Lichfield, Ludlow, Macclesfield, Matlock, Nottingham, Oldham, Richmond, Scarborough, Sheffield, South Shields, Stockport, Sunderland, Tynemouth, Walsall, Warrington, Warwick, Weymouth, Wigan,

Wolverhampton 


\section{Notes}

${ }^{1}$ D. Defoe, A Tour through the Whole Island of Great Britain (1724-6, Penguin edition: Harmondsworth, 1971), 397.

${ }^{2}$ This tradition can be traced back to P. Clark and P. Slack, English Towns in Transition 1500-1700 (Oxford, 1976) and has been seen most recently in P. Clark (ed.) Cambridge Urban History of Britain. Volume II 1540-1840 (Cambridge, 2000).

${ }^{3}$ P. Corfield, The Impact of English Towns 1700-1800 (Oxford, 1982), 11.

${ }^{4}$ See J. Stobart, The First Industrial Region: North-west England, c.1700-1760 (Manchester, 2004), chapter 2.

${ }^{5}$ B. Robson, Urban Growth: an approach (London, 1973); A. Pred, City Systems in Advanced Economies (London, 1977); B. Lepetit, The Pre-industrial Urban System: France, 1740-1840 (Cambridge, 1994).

${ }_{6}$ This transition is modelled by J.W. Simmons, 'The Organization of the Urban System', in L.S. Bourne and J.W. Simmons (eds), Systems of Cities: Readings on Structure, Growth, and Policy (New York, 1978), 61-9

${ }^{7}$ P. Borsay, 'Health and leisure resorts 1700-1840', in Clark (ed.) Cambridge Urban History, Volume II, 775-804.

8 D. Reeder and R. Rodger, 'Industrialisation and the city economy', in M. Daunton (ed.) Cambridge Urban History of Britain. Volume III 1840-1950 (Cambridge, 2000), 565-85; P. Borsay, The English Urban Renaissance. Culture and Society in the Provincial Town, 1660-1770 (Oxford, 1989); B. Trinder, 'Industrialising towns 17001840', in Clark (ed.) Cambridge Urban History, Volume II, 805-30.

${ }^{9}$ R. Sweet, 'Topographies of politeness', Transactions of the Royal Historical Society, 22 (2002), 355-74.

${ }^{10}$ L.D. Schwarz, 'Residential leisure towns in England towards the end of the eighteenth century', Urban History, 27 (2000), 51-61. For more detailed discussion of the tax itself, see L.D. Schwarz, 'English servants and their employers during the eighteenth and nineteenth centuries', Economic History Review, 52 (1999), $236-56$.

${ }^{11}$ See Sweet, 'Topographies of politeness', 360-62.

${ }^{12}$ M. Berg, Luxury and Pleasure in Eighteenth-Century Britain (Oxford, 2005), 21-45 (quote from 37). See also W. Smith, Consumption and the Making of Respectability, 1600-1800 (London, 2002), 63-103.

${ }_{13}$ T. Veblen, The Theory of the Leisure Class (London, 1912); Schwarz, 'Residential leisure towns', 54.

${ }^{14}$ Ellis, J., "For the honour of the town": comparison, competition and civic identity in eighteenth-century England', Urban History, 30 (2003), 325-37.

${ }_{15}$ The residential leisure towns and the control group are listed in Appendix I.

${ }_{16}$ These data are drawn from the Universal British Directory; Borsay, English Urban Renaissance, 323-54; Stobart, Hann and Morgan, Spaces of Consumption, chapter 2, and a wide range of local histories and directories.

${ }^{17}$ Blome, Britannia, 175; Defoe, 406.

${ }^{18}$ For details of this tax, see S. Dowell, History of Taxation and Taxes in England, Vol. 3, Book 3 (London, 1883), 209-15. The number of households liable for the silver plate duty in each town u is taken from P. Langford, $A$ Polite and Commercial People. England 1727-1783 (Oxford, 1989), 402-3.

${ }^{19}$ Berg, Luxury and Pleasure, 162-8. It was indeed only practical to tax silver plate whilst its use was restricted. 20 Schwarz, 'Residential leisure towns', 57-8.

21 P. Elliot, 'Towards a geography of English scientific culture: provincial town identity and literary and philosophical culture in the English county town, 1750-1850', Urban History, 32 (2005), 391-412.

${ }^{22}$ Ellis, 'For the honour of the town'. 
${ }^{23}$ See Borsay, English Urban Renaissance, 39-113; J. Stobart, 'In search of a leisure hierarchy', in P. Borsay, G. Hirschfelder and R. Mohrmann (eds) New Directions in Urban History. Aspects of European Art, Health, Tourism and Leisure since the Enlightenment (Munster, 2000), 19-40; Ellis, 'For the honour of the town'; J. Stobart, A. Hann and V. Morgan, Spaces of Consumption: Leisure and Shopping in the English Town, c.1680-1830 (London, 2007), 57-85.

24. David Hume, 'Of luxury' in Essays and Treatises on Several Subjects (1758), 157: quoted in Sweet, 'Topographies of politeness', 356.

25 'A. McInnes, 'The emergence of a leisure town: Shrewsbury 1660-1760' Past and Present, 120 (1988), 53-87; R. Sweet, The English Town 1680-1840. Government, Society and Culture (London, 1999), 25 1-6.

${ }^{26}$ Even establishing the presence of a function can be problematic, especially in the case of assemblies and music concerts - one-off events have been discounted from the present analysis.

27 There are, of course, problems with the data: the apparent absence of a function from a town may mean that it was not there or merely that we have found no record of its presence. The figures presented in Table 1 should be treated as minima rather than exhaustive lists. Even allowing for under-counting in lesser towns, the focusing of these facilities and improvements into residential leisure towns remains clear.

28 Borsay, English Urban Renaissance, 183-5; Stobart, Hann and Morgan, Spaces of Consumption, 26-56.

29 This exercise took population into account. Facilities per thousand of population were averaged for the two groups and compared.

${ }^{30}$ J. Beckett and C. Smith, 'Urban renaissance and consumer revolution in Nottingham, 1688-1750', Urban History, 27 (2000), 31-50.

31 J. Stobart, 'Building an urban identity. Cultural space and civic boosterism in a 'new' industrial town: Burslem, 1761-1911', Social History, 29 (2004), 490.

32 Blome, Britannia, 204, 230, 232.

33 See L. Schwarz, 'On the margins of industrialisation: Lichfield, 1700-1840', in J. Stobart and N. Raven, Towns, Regions and Industries. Urban and Industrial Change in the Midlands, 1700-1840 (Manchester, forthcoming, 2004); V. Morgan, 'Producing consumer space in eighteenth-century England' (Unpublished PhD thesis, Coventry University, 2003).

${ }^{34}$ Beattie, D., Blackburn: The Development of a Lancashire Cotton Town (Halifax, 1992), 115.

${ }_{35}$ Borsay, English Urban Renaissance, 333-4; Morgan, 'Producing consumer space'.

${ }^{36}$ For a fuller discussion, see R. Sweet, The Writing of Urban Histories in Eighteenth-Century England (Oxford, 1997). Numbers of town histories are taken from 295-310.

${ }^{37}$ See Stobart, Hann and Morgan, Spaces of Consumption, 92-8.

${ }^{38}$ Borsay, English Urban Renaissance; M. Girouard, The English Town (New Haven, 1990), 101-26, 155-70.

${ }^{39}$ Girouard, English Town, 127-44; Stobart, 'Leisure hierarchy', 25-30; V. Green, Survey of the City of Worcester (Worcester, 1764), 228-30.

40 Borsay, English Urban Renaissance, 329; J. Platt, The History and Antiquities of Nantwich (London, 1818), 76-7.

${ }^{41}$ S. Ryley, The Itinerant or Memoirs of an Actor (London, 1808), 263-4; Defoe, Tour of Great Britain, 360.

${ }^{42}$ See Stobart, Hann and Morgan, Spaces of Consumption, chapters 1 and 6.

${ }^{43}$ Defoe, Tour of Great Britain, 142.

44. Borsay, English Urban Renaissance, 225-83; Langford, Polite and Commercial People, 61-84, 116-121. The avoidance of excessive intimacy with social inferiors who happened to be in the same room also became an art 
at which the English were renowned internationally: P. Langford, The uses of Eighteenth-Century Politeness', Transactions of the Royal Historical Society, 22 (2002), 311-31.

${ }_{45}$ For a general appraisal of the source, see J.R. Walton, 'Trades and professions in late eighteenth-century England: assessing the evidence of directories', The Local Historian, 17 (1987), 343-50.

${ }_{46} \mathrm{~J}$. Ryley, A History of the Town and Parish of Leeds (Leeds, 1797); E. Raffald, Directory of Manchester and Salford (Manchester, 1781); P. Broster, The Chester Guide (Chester, 1782); W. Cowdroy, The directory and guide for the City and County of Chester (Chester, 1784).

${ }^{47}$ In Hull, for example, the $U B D$ records fifteen of these trades and a total of 94 tradesmen giving a retail score of $(15 \times 94=)$ 1410; for Shrewsbury, there were fifteen trades, but only sixty-two tradesmen giving a score of 930. For use of this technique in analysis of a regional urban network, see J. Stobart and A. Hann, 'Retailing revolution in the eighteenth century: evidence from north-west England', Business History, 46 (2004), 171-94.

${ }^{48}$ The Spearman's Rank Correlation Coefficient is 0.637, suggesting a close correlation between the two series.

${ }_{49}$ At the opposite end of the scale, around one-quarter of both county and commercial towns were counted amongst the lowest order centres.

${ }^{50}$ This matches the findings of the more impressionistic survey undertaken by Stobart, 'Leisure hierarchy'. See also the arguments in J. Ellis, 'Regional and county centres, 1700-1840', in P. Clark (ed.) The Cambridge Urban History of Britain, volume II 1540-1840 (Cambridge, 2000), 673-704.

51 Whilst lower than that that between employers of manservants and luxury service score (0.637), the correlation between population and luxury service score is statistically significant.

${ }_{52}$ Those that remain in the top twenty are Liverpool (which has the highest luxury service score, but falls to twentieth when population is taken into account), Bristol (which goes from third to eighteenth), and Newcastle (which falls from sixth to fourteenth). Of the others, Manchester falls from second to thirty-first, and Birmingham from fifth to fifty-second.

${ }^{53}$ Stobart, Hann and Morgan, Spaces of Consumption, chapter 3.

${ }_{54}$ A. Vickery, 'Women and the world of goods: a Lancashire consumer and her possessions, 1751-81, in J. Brewer and R. Porter (eds) Consumption and the World of Goods (London, 1993), 274-301; H. Whitbread (ed.) I Know my own Heart: The Diaries of Anne Lister (London, 1988), 105, 245-55.

${ }_{55}$ Cheshire and Chester Archives, WS 1728 Zacariah Shelley of Congleton, WS1716 Richard Upton of Stockport, WS1702 James Rathbone of Macclesfield.

${ }^{56}$ S.I. Mitchell, 'The development of urban retailing 1700-1815', in P. Clark (ed.), The Transformation of English Provincial Towns 1600-1800 (London, 1984), 259-83; J. Stobart, 'County, town and country: three histories of urban development in eighteenth-century Chester', in P. Borsay and L. Proudfoot (eds), Provincial Towns in Early Modern England and Ireland: Change, Convergence and Divergence (Oxford, 2002), 171-94.

${ }^{57}$ V. Green, Survey of the City of Worcester (Worcester, 1764), p.235; J. Hemingway, History of the City of Chester (Chester, 1831), vol. 1, 388.

${ }^{58}$ For more detailed analysis of Bath's attraction to national figures, see P. Borsay, The Image of Georgian Bath, 1700-2000 (Oxford, 2000), 99-142, 396-9.

${ }^{59}$ Sweet, 'Topographies of politeness', 364-5.

${ }^{60} \mathrm{~J}$. Wallace, A General and Descriptive History of Liverpool (Liverpool, 1795), 283. See J. Stobart, 'Culture versus commerce: societies and spaces for elites in eighteenth-century Liverpool', Journal of Historical Geography, 28 (2002), 474-6. 
${ }^{61}$ Ellis, 'Regional and county centres', 697-702.

${ }^{62}$ Gore's Advertiser, 23 February 1770.

${ }^{63}$ See Sweet, 'Topographies of politeness', 365-6.

${ }^{64}$ E. Raffald, Directory of Manchester and Salford (Manchester, 1773); A. Kennett, Georgian Chester (Chester, 1987), 26-31 and 36-41.

${ }^{65}$ Hemingway, Chester, vol.2, 341.

$66 \mathrm{~J}$. Ellis, 'For the honour of the town'.

${ }_{67}$ Taken from Schwarz, Residential leisure towns, 56-7. 